\title{
Analisis Pemikiran Ekonomi Islam Imam Abu Hanifah
}

\author{
Nabila Zatadini \\ Pasca Sarjana Prodi Hukum Ekonomi Syariah \\ Universitas Darussalam Gontor \\ ratadini.nabila@gmail.com
}

Mohammad Ghozali

Pasca Sarjana Prodi Hukum Ekonomi Syariah

Universitas Darussalam Gontor

mohammadghozali@unida.gontor.ac.id

\begin{abstract}
Islamic economics has been practiced since the time of the Prophet Muhammad, but at that time until several centuries later there is no classification of specific disciplines for economics, causing some Muslim works lost by the western historians drowned. Therefore it is necessary to study the classical Islamic economic thinking. This paper aims to review Abu Hanifah's economic ideas by comparing it with the opinion of some scholars and match whether Abu Hanifah's thoughts can be used today. The method used is literature research with documentary method to collect data. The results of this study, that Abu Hanifah does not have a special idea in the economy but has a special view in every akeqqhatat fiqh such as greetings, charity honey, and hawalah. Some of Abu Hanifah's opinions are different from other priests causing a Muslim today to sort out the khilafiyah.
\end{abstract}

Keywords: Pemikiran ekonomi; Imam Abu Hanifab; Akad-akad muamalah

\begin{abstract}
Abstrak
Ekonomi Islam sudah dipraktekkan semenjak zaman Rasulullah SAW, namun pada saat itu hingga beberapa abad selanjutnya belum ada klasifikasi disiplin ilmu khusus untuk ekonomi sehingga menyebabkan beberapa karya muslim hilang ditenggelamkan oleh sejarawan barat. Maka dari itu perlu dilakukan kajian mengenai pemikiran ekonomi islam klasik. Makalah ini bertujuan untuk mengkaji ulang pemikiran-pemikiran ekonomi Abu Hanifah dengan membandingkannya dengan pendapat beberapa ulama dan menyocokkan akankah pemikiran Abu Hanifah dapat digunakan hingga saat ini. Metode yang digunakan adalah penelitian literatur dengan metode dokumenter untuk mengumpulkan data. Hasil dari penelitian ini, bahwa Abu Hanifah tidak memilki gagasan khusus dalam ekonomi namun memilki pandangan khusus dalam setiap akad figh muamalat seperti salam, zakat madu, dan hawalah. Beberapa pendapat Abu Hanifah berbeda dengan imam lainnya menyebabkan seorang muslim saat ini harus memilah-milah agar keluar dari khilafiyah.
\end{abstract}

Al Falah: Journal of Islamic Economics, Vol. 3, No. 1, 2018

STAIN Curup|E-ISSN: 2548-3102, P-ISSN: 2548-2343

Available online: http://journal.staincurup.ac.id/index.php/alfalah 
30 |Al-Falah: Journal of Islamic Economics, Vol.3, No.1, 2018

Kata Kunci: Pemikiran ekonomi; Imam Abu Hanifah; Akad-akad muamalah

\section{PENDAHULUAN}

Pada dasarnya, ekonomi Islam sudah dipraktekkan sejak 14 abad yang lalu oleh Nabi Muhammad SAW. Praktek tersebut mencakup larangan bai' najasy, ${ }^{1}$ talaqqi rukban, ${ }^{2}$ dan masih banyak lagi kebijakan-kebijakan ekonomi Islam pada saat itu. ${ }^{3}$ Praktek ekonomi tersebut dilanjutkan oleh ulama-ulama muslim dan menuliskannya dalam karya tulis. Para ulama menuliskan praktek ekonomi islam tidak dalam disiplin ilmu khusus, namun menjadi satu dengan ilmu fiqh, muamalat, aqaid dan lain sebagainya. Adapun ulama yang menuliskan ilmu ekonomi Islam dalam karyanya ialah Abu Hanifah dengan kitab Al-Makharif fi Al-Figh, Abu Ubaid dengan Al-Amwal, Yahya bin Umar dengan Abkam al-Suq, dan masih banyak lagi. ${ }^{4}$

Sayangnya, ilmu ekonomi Islam dalam karya-karya ulama tersebut belum terorganisir sebagai disiplin ilmu khusus hingga akhirnya menyebabkan ekonomi Islam terhapuskan oleh sejarah. Joseph Schumpeter, sejarawan dan ekonom terkemuka. Dia menyatakan bahwa ekonomi dimulai oleh para filsuf Yunani dan dilanjutkan dengan pemikiran St. Thomas Aquinas, 500 tahun setelahnya. Lima abad jarak antar Yunani dan Aquinas dikenal sebagai Great Gap. Dalam waktu yang begitu lama, sejarawan barat hanya menyatakan bahwa waktu itu tidak produktif, jadi tidak ada yang bisa dijelaskan di dalamnya. ${ }^{5}$ Itulah yang menyebabkan hilangnya ekonomi Islam.

Hilangnya ekonomi Islam mengharuskan umat manusia mengikuti konsep ekonomi konvensional. Konsep yang penuh dengan riba' menyebabkan penduduk dunia rusak sedikit demi sedikit, dengan cekikan hutang, inflasi, ketimpangan yang berujung pada kemiskinan yang tidak dapat diberantas. Seperti Indonesia yang diduduki oleh 26,58 juta orang (10,12 persen) warga

${ }^{1}$ Bai' najasy adalah memuji barang dagangan seseorang agar barang laris terjual.

${ }^{2}$ Talaqqi rukban adalah pedagang yang menjual barangnya sebelum ia sampai di pasar

${ }^{3}$ Nur Chamid, Jejak Langkah Sejarah Pemikiran Ekonomi Islam, (Yogyakarta: Pustaka Pelajar, 2010), h.26-30.

${ }^{4}$ Kitab ulama lain yang membahas mengenai ekonomi islam: Al-Mawardi [Adab Al-Dunya Wa Al-Din], Al-Ghazali [Ihya Ulumu Al-Din], IbnTaymiyya [Al-Hizbah fi Al-Islam], Al-Syatibi [Al-Muwafaqat fi Ushul Al-Syari'ah], Ibn Khaldun [AlMuqaddimah], and Al -Maqrizi [Ighatsah Al-Ummah bi Kasyf Al-Ghummah].

${ }^{5}$ Abbas Mirakhor, Muslim Contribution to Economics, in the book Baqir al-Hasanidan Abbas Mirakhor, Essays on Iqtisad: The Islamic Approach to Economic Problems (USA: NurCoorporation, 1989), h.82-86. 
miskin hingga September 2017 lalu. ${ }^{6}$ Selain kemiskinan, Indonesia juga dilanda kelangkaan bahan bakar minyak. Seperti yang dilansir dari Sindo News, Wakil Menteri Energi dan Sumber Daya Mineral (ESDM) Arcandra Tahar mengungkapkan bahwa energi fosil berupa cadangan minyak dan gas bumi (migas) Indonesia diperkirakan habis dalam 12 tahun mendatang. ${ }^{7}$

Untuk mengatasi masalah-masalah ekonomi tersebut diperlukan adanya sebuah penelitian yang mengkaji kembali konsep-konsep ekonomi menurut ulama-ulama muslim terutama Imam yang diikuti madzhabnya oleh umat muslim di dunia, seperti Imam Abu Hanifah. Abu Hanifah merupakan ulama yang berpikir rasional positif, ia tidak hanya melihat dari Qur'an maupun Sunnah namun dikombinasikan dengan rasional yang berbentuk kaidah istihsan. Sehingga sangat cocok pemikiran ekonominya dikaji mengingat ekonomi adalah ilmu sosial yang harus terus melihat ke lapangan.

Adapun metode kajian yang digunakan dalam membahas permasalahan ini yaitu penelitian literatur. ${ }^{9}$ Data dalam penelitian ini didapat dengan menggunakan metode dokumenter, untuk mencari data-data tentang pemikiran Imam Abu Hanifah mengenai ekonomi Islam, antara lain yang bersumber dari buku, jurnal, internet, dan makalah. Metode analisis data yang digunakan adalah induktif, deduktif, dan analisis deskriptif komparatif.

\section{HASIL DAN PEMBAHASAN}

\section{Biografi Imam Abu Hanifah}

Imam Abu Hanifah lahir di Kufah pada tahun $80 \mathrm{H}$ pada masa khilafah Abdul Malik bin Marwan. Ia lahir dengan nama Nu'man bin Tsabit bin Marzuban, dari keturunan Persia. Abu Hanifah aslinya berasal dari Kabul Ibukota Afghanistan saat ini, namun kakeknya Marzuban masuk Islam pada masa khilafah Umar bin Khattab yang akhirnya membuat ia pindah ke Kufah dan menetap di sana. ${ }^{10}$

6Lihat Persentase Penduduk Miskin September 2017 Mencapai 10,12 persen: https://www.bps.go.id/pressrelease/2018/01/02/1413/persentase-penduduk-miskinseptember-2017-mencapai-10-12-persen.html

${ }^{7}$ Lihat artikel Minyak Indonesia Diperkirakan Habis 12 Tahun Lagi: https://ekbis.sindonews.com/read/1225346/34/minyak-indonesia-diperkirakan-habis12-tahun-lagi-1501398668 h. 231

${ }^{8}$ Abdul Karim Zida, Al-Wajir fi Usul Fiqh, (Giza: Muassasah Cordova, 1976),

9Sugiono, Metode Penelitian Kuantitatif, Kualitatif Dan R \& D, (Bandung: Alfabeta, 2014), h. 240

${ }^{10}$ Wahbi Sulaiman Ghawiji, Abu Hanifah Nu'man Imam al-Aimmah al-Fuqaha', (Beirut: Darul Qalam, 1993), h.47 
Sementara mengenai kehidupan ayahnya, belum ada sumber yang menjelaskan secara terperinci tentang itu, hanya sebagian keadaan yang diketahui. Ayahnya adalah pedagang muslim yang baik serta kaya. Diketahui pula bahwa ayahnya bertemu dengan Ali bin Abi Thalib saat kecil dan kakeknya memberi 'Ali beberapa faludhaj ${ }^{11}$ pada hari Nawruz. ${ }^{12}$ Hal ini menunjukkan bahwa keluarganya kaya karena mereka bisa memberikan manisan khalifah atau faludhaj yang hanya bisa dimakan oleh orang kaya. ${ }^{13}$ Dapat disimpulkan dari kejadian tersebut bahwa Tsabit merupakan orang kaya.

Pernyataan bahwa Tsabit adalah seorang muslim terbukti dari suatu peristiwa. Hal ini terkait bahwa 'Ali berdoa memohon berkah dari Allah SWT. bagi Thabit dan keturunannya saat dia melihatnya. Ini menunjukkan bahwa dia pastilah seorang Muslim. Ini secara eksplisit menyatakan dalam sejarah bahwa Thabit lahir dalam Islam dan Abu Hanifa tumbuh di rumah tangga Muslim. Itu dikonfirmasi oleh semua ilmuwan. Sedangkan pernyataan bahwa ia adalah seorang pedagang terbukti dari para penduduk yang menemukan Abu Hanifah sering mengunjungi pasar sebelum dia sering belajar. Dia terlibat dalam perdagangan dan jadi dapat disimpulkan bahwa ayahnya adalah seorang pedagang. Sepertinya dia adalah seorang pedagang sutra di $K h a z q^{14}$ dan bahwa Abu Hanifah mengikuti pekerjaan ayahnya. ${ }^{15}$

Abu Hanifah berkepribadian sangat cerdas dan bijak. Imam Ali bin Aasim mengatakan, "Jika kecerdasan Imam Abu Hanifah harus ditimbang dengan kecerdasan setengah dari orang-orang dunia maka kecerdasan Imam Abu Hanifah akan menggantikan mereka semua." Hal itu terbukti dengan kejadian di saat seorang pria bertengkar dengan istrinya dan selama pertengkaran sang istri memegang secangkir air dan berjalan ke arah suami dan berkata, 'Jika kau minum air dari cangkir ini, maka ada tiga talaq ${ }^{16}$ atasmu; jika kamu jatuhkan

${ }^{11}$ Faludhaj adalah manisan khas Persia terbuat dari madu, minyak wijen dan kacang almond panggang.

${ }^{12}$ Nawruz adalah perayaan tahun baru secara tradisional di Iran, Azerbaijan, Afganistan, Pakistan, beberapa bagian India, dan di antara suku bangsa Kurdi. Serta seluruh negara Asia dan Afrika yang menyerap budaya Persia.

${ }^{13}$ Muhammad Abu Zahra, Imam Abu Hanifa, His Life, Opinions and Figh, (Makkah: Maktabah Publication, 1945), h.7-8

${ }^{14}$ Kharz adalah etnik komunitas Muslim di Khazaria atau kota Khazaran

${ }^{15}$ Muhammad Abu Zahra, Imam Abu Hanifa, His Life, Opinions and Fiqh, h.8

${ }^{16}$ Talaq adalah memustus atau melepas ikatan perkawinan antara sepasang suami dan istri yang ditandai dengan pengucapan lafadz 
(tuangkan) ke tanah juga ada tiga talaq atas kamu; dan bahkan jika kau memberikannya kepada orang lain untuk diminum, ada tiga talaq di hadapamu. ${ }^{17}$

Setelah kemarahan suami mereda, dia menyadari apa yang telah dilakukannya dan ia datang kepada seluruh ulama untuk membantunya keluar dari masalah tersebut namun tidak ada yang bisa menemukan solusi untuk menghentikan talaq. Akhirnya, dia mendatangi Imam Abu Hanifah dan menceritakan kasusnya. Abu Hanifah berkata, "Masukkan lap ke cangkir dan rendamlah di dalamnya. Dengan cara ini, anda akan bebas dari ancaman talaq dan anda istri akan diselamatkan dari Talaq." 18 Itulah salah satu dari bukti bahwa Imam Abu Hanifah adalah seorang yang cerdas.

Bukan hanya cerdas, ia juga sangat amat mencintai qur'an membuatnya rajin membaca qur'an dan mengkaji kandungannya diikui pengkajian hadits dan fiqh, namun pengkajiannya harus terputus demi mengikuti ayahnya yang berdagang hingga ia bertemu dengan Amir Al-Sha'bi ${ }^{19}$ dalam perjalanannya ke pasar. $^{20}$

Al-Sha'bi memanggilnya dan bertanya kemana Abu Hanifah akan pergi, ia menjawab ia akan pergi ke seorang pedagang, Al-Sha'bi berkata bahwa beliau tidak melarangnya untuk pergi ke pasar namun bermaksud memanggil seorang ulama, Abu Hanifah berkata bahwa ia tidak pernah memanggil ulama sekalipun, kemudian Al-Shabi menyuruh Abu Hanifah untuk belajar ilmu khususnya ilmu agama dan duduk di majlis ulama karena beliau melihat tanda-tanda kecerdasan dan energi di dalam dirinya. ${ }^{21}$ Setelah kejadian tersebut Abu Hanifah memiliki dorongan kuat untuk mempelajari berbagai ilmu.

Sejak saat itu, Imam Abu Hanifah mempelajari berbagai macam ilmu. Ilmu pertama yang dipelajarinya adalah ilmu kalam atau ushuluddin. Berawal dari perdebatannya dengan orang atheis dan sesat, dilanjutkan dengan diskusi dan perdebatannya di Basrah lebih dari 27 kali. Bahkan ketika berdebat dengan Jahm bin Safwan, ia dapat membungkamnya karena kecerdasan Abu Hanifah dalam

${ }^{17}$ Ghaus-ul-Waqt Huzoor Mufti-e-Azam Hind, The Importance of Fiqh \& A Brief Introduction to Imam Azam Abu Hanifa, (Durban: Imam Mustafa Raza Research Centre, 2014), h.19

${ }^{18}$ Ghaus-ul-Waqt Huzoor Mufti-e-Azam Hind...

${ }^{19} \mathrm{Al}-\mathrm{Sha}$ 'bi adalah penerus ulama terkemuka dan dianggap sebagai guru Abu Hanifa yang paling senior.

${ }^{20}$ Mohammed Akram Nadwi, Abu Hanifah: His Life, Legal Method \& Legacy, (Leicestershire: Kube Publishing, 2011), h.92

${ }^{21}$ Dikutip dari Makki Manaqib dalam buku Mohammed Akram Nadwi, Abu Hanifah: His Life, Legal Method \& Legacy, h.92 
berdebat. Selain itu ia juga membuat orang atheis mengakui syariat Islam. ${ }^{22}$ Hingga akhirnya ia menjadi ahli ilmu kalam khususnya yang berkenaan dengan fiqh.

Karena Abu Hanifah berminat pada fiqh akhirnya ia memutuskan untuk mempelajari fiqh. Ia memilih Hammad bin Abi Sulayman Al-Kufi sebagai gurunya. Beliau adalah Imam yang terkenal dan dikenal sebagai ahli fiqh di Kufah, ia telah mendengar hadits dari Anas bin Malik, Hasan Al-Barsi, Said bin Jubayr, Abu Wa'il, Said bin Al-Musayyab, Amir Al-Shabr dan Abdullah bin Buraydah. Beliau mempelajari fiqh dari Ibrahim Al-Nakha'i, menemani hingga akhir hayat Al-Nakha'i hingga menjadi murid yang paling menonjol dan berhasil menggantikannya memimpin sekolah fiqh di Kufah yang menghasilkan banyak ulama fiqh yang hebat seperti Mis'ar bin Kidam, Sufyan Al-Thawri, Shu'bah bin Hajjaj dan lain sebagainya. ${ }^{23}$

Abu Hanifah belajar kepada Hammad selama 18 tahun sejak ia berumur 20 tahun hingga wafatnya Hammad pada tahun $120 \mathrm{H}$. Sejak saat itu, Abu Hanifah menggantikannya sebagai guru utama figh di Kufah. Ketenarannya menyebar, para ahli hadis dan figh hadir, orang-orang dari setiap kota besar di dunia islam datang untuk belajar bersamanya. ${ }^{24}$

Selain berguru pada Hammad, Abu Hanifah juga berguru pada ulama lainya. Ia berguru kepada 4.000 ulama, yang terdiri dari 7 shahabah, 93 tabi'in, dan sisanya tabi'u tabiin. Tidak heran jika ia dapat belajar dari guru sebanyak itu, karena ia hidup hampir 70 tahun dan menunaikan haji 55 kali selama hidupnya dimana pada saat itu adalah waktu bagi para ulama berkumpul di masjidil haram. ${ }^{25}$

Selain memiliki guru yang banyak, Abu Hanifah juga memliki murid yang sangat banyak hingga mencapai ribuan. Adapun murid-murid yang paling terkenal adalah Abu Yusuf, ibnu Mubarak, Muhammad bin Hasan, Yahya bin Zakaria, Hibban, Qasim bin Ma;na bin Abdurrahman bin Abdullah bin Mas'ud, Daud Al-Tha'i, Fadhil bin 'Iyadh. ${ }^{26}$

22Wahbi Sulaiman Ghawiji, Abu Hanifah Nu'man Imam al-Aimmah al-Fuqaha', h. 50

${ }^{23}$ Mohammed Akram Nadwi, Abu Hanifah: His Life, Legal Method \& Legacy, h. 93

94

${ }^{24} \mathrm{Al}-\mathrm{Dh} a h a b i$, Manaqib al-Imam Abu Hanifa wa Sahibaihi, (Egypt: Dar al-Kutub al-'Arabi), h. 115.

${ }^{25}$ Wahbi Sulaiman Ghawiji, Abu Hanifah Nu'man Imam al-Aimmah al-Fuqaha', h. 57

${ }^{26}$ Wahbi Sulaiman Ghawiji, Abu Hanifah Nu'man Imam al-Aimmah al-Fuqaha', h.66- 
Kekayaan ilmu Abu Hanifah tertuang pada buku-bukunya seperti: Kitab Al-Athar, Ilmu Kalam Al-Fiqh Al-Akbar Wa Al-Fiqh Al-Ausath, Kitab Al-'Alim Wa Al-Mut'allim, Kitab Al-Risalah, Kitab Al-Risalah Ila Ustman. Selain itu Abu Hanifah menulis hadits dan mengumpulkannya, serta menulis tentang fiqh, aqaid dan lain sebagainya. $^{27}$

\section{Metodologi Pemikiran Imam Abu Hanifah}

Imam Imam abu hanifah berlandaskan lima adilab ${ }^{28}$ dalam istinbath abkam ${ }^{29}$. Adilah menurut Abu Hanifah terdiri dari lima hal, yaitu: Qur'an, Sunnah, ijma' qiyas dan istihsan. Pendapatnya ini berlandaskan dengan sunnah nabi riwayat Abu Daud:

Bahwa Rasulullah ketika akan mengutus Mu'adz bin Jabal ke Yaman beliau bersabda: Bagaimana engkau memberikan keputusan apabila ada sebuah peradilan yang dihadapkan kepadamu? Mu'adz menjawab, Saya akan memutuskan menggunakan Kitab Allah. Beliau bersabda: Seandainya engkau tak mendapatkan dalam Kitab Allah? Mu'adz menjawab, Saya akan kembali kepada sunnah Rasulullah. Beliau bersabda lagi: Seandainya engkau tak mendapatkan dalam Sunnah Rasulullah serta dalam Kitab Allah? Mu'adz menjawab, Saya akan berijtihad menggunakan pendapat saya, \& saya tak akan mengurangi. Kemudian Rasulullah menepuk dadanya \& berkata: Segala puji bagi Allah yg telah memberikan petunjuk kepada utusan Rasulullah untuk melakukan apa yg membuat senang Rasulullah. [HR. Abudaud No.3119].

Abu Hanifah menempatkan derajat mujtahid untuk dirinya sendiri. Jika ketika istinbath ahkam ia tidak menemukan dalil di Quran, ia mencari di Sunnah. Jika belum ditemukan maka ia mencari ijma' sahabat Rasulullah. Dan apabila setelah rangkaian ijtihad tersebut masih belum ditemukan dalil yang sesuai, ia akan melakukan qiyas dan istihsan sebagaimana yang dikerjakan oleh tabi'in. karena menurutnya ia memiliki derajat yang sama dengan tabi'in, samasama hidup sebagai muslim yang tidak hidup semasa hidupnya Rasulullah SAW. ${ }^{30}$

Dari seluruh metode yang digunakan Abu Hanifah, yang paling berbeda adalah istihsan. Tidak semua ulama menggunakan metode ini dalam istinbath h.289-296

${ }^{27}$ Wahbi Sulaiman Ghawiji, Abu Hanifab Nu'man Imam al-Aimmah al-Fuqaha'

${ }^{28}$ Adilah adalah kata majemuk dari dalil atau landasan dalam menentukan hokum suatu hal

${ }^{29}$ Istinbath Abkam adalah aktivitas ulama menentukan hokum suatu hal dari dalildalil. Cara istinbath abkam satu ulama lain dan lainnya berbeda-beda.

${ }^{30}$ Ahmad Asy-Syahbashi, Al-Aimmah Al-Arba'ah, (Mesir: Darul Hilal), h.29 
abkam. Istihsan dimaknakan sebagai ijtihad seorang mujtahid dengan berpindah dari ketentuan qiyas jali (yang jelas) kepada ketentuan qiyas khafi (yang samar), atau ketentuan yang kulli (umum) kepada ketentuan istisna'i (pengecualian atau khusus), dalam ahkam yang belum dijelaskan Allah dalam kitab-Nya. ${ }^{31}$

Dari metodenya yang membolehkan istihsan dan berbagai solusi masalah yang dikemukakan Abu Hanifah berdasarkan akal pikiran, terlihat bahwa pemikiran Abu Hanifah berbasis pada nalar burhani. ${ }^{32}$ Basis nalar burhani tersebut membuat Abu Hanifah tidak dapat menafikan kondisi sosio-historis, sosiokultural dan letak geografisnya saat berijtihad. Hidupnya di kota metropolitan Kufah dan Baghdad menyebabkannya lebih mengedepankan rasionalitas dan juga lebih mengedepankan rasionalnya dari pada hadis-hadis nabi yang tidak masybur. ${ }^{33}$

Rasionalitas Abu Hanifah dibatasi oleh prinsip yang ia pegang teguh. Prinsip tersebut terdiri dari lima hal. Pertama, memberikan hak-hak fakir miskin, seperti wajib berzakat dari pakaian berbahan emas kepada gharim. Kedua, kemudahaan dalam ibadah dan kegiatan sehari-hari. Contohnya adalah ketika seseorang bingung di mana arah qiblat, maka bolehlah ia sholat menghadap qiblat yang ia yakini. Ketiga, menjaga kehormatan dan perikemanusiaan. Contohnya: Abu Hanifah menyatakan bahwa nikah anak perempuan yang dipaksa itu tidak sah. ${ }^{34}$

Prinsip keempat, memberikan kuasa penuh kepada pemerintahan negara. Seperti, pemerintah, kerajaan, khalifah atau pemimpin negara berhak mengatur keuangan negara yang beredar di negara tersebut. Kelima, mengikut perkembangan dan peradaban manuia. Jadi Abu Hanifah tidak hanya berpikir normative tapi juga dipadukan dengan positif. Contohnya, wasiat seorang ayah kepada anaknya untuk memelihara anak yatim. ${ }^{35}$

\section{Pemikiran Ekonomi Imam Abu Hanifah}

${ }^{31}$ Abdul Karim Zida, Al-Wajir fi Usul Figh, h.231

${ }^{32}$ Burhani adalah aktivitas berpikir untuk menetapkan kebenaran suatu premis melalui metode penyimpulan (al-istintaj), dengan menghubungkan premis tersebut dengan premis yang lain yang oleh nalar dibenarkan atau telah terbukti kebenarannya (badlibiyyah).

${ }^{33}$ M. Iqbal Juliansyahzen, 'Pemikiran Hukum Islam Abu Hanifah: Sebuah Kajian Sosio-Histori Seputar Hukum Keluarga', AL-Madzahib, Volume 3, Nomer 1, Juni 2015, (71-85), h.82-83

${ }^{34}$ Abdurrahman Kasdi, 'Metode Ijtihad Dan Karakteristik Fiqih Abu Hanifah', Yudisia, Jurnal Pemikiran Hukum Dan Hukum Islam, Vol. 5, No. 2, Desember 2014, h.223-224

${ }^{35}$ Abdurrahman Kasdi, 'Metode Ijtihad Dan Karakteristik Fiqih Abu Hanifah'... 
Imam Abu Hanifah terkenal sebagai pemuka madzhab dalam masalah fiqh. Sehingga tidak ditemukan kebijakan-kebijakan atau gagasa-gagasan khusus mengenai ekonomi yang ditawarkan oleh Abu Hanifah, namun ia mengemukakan banyak pendapat dalam akad-akad muamalat dalam segi pandang fiqh. Adapun beberapa pemikiran Ekonomi Abu Hanifah adalah sebagai berikut:

\section{Akad Salam}

Pemikiran Abu Hanifah yang akan dibahas terlebih dahulu adalah mengenai salam. ${ }^{36}$ Abu Hanifah sepakat dengan ulama lainnya mengenai syarat salam yang enam. Syarat pertama adalah harga barang harus diketahui jenisnya, apakah dengan uang atau barang berharga lainnya. Kedua, harus diketahui harga pastinya. Ketiga, menyerahan harga sebagai modal pedagang harus dilakukan di majlis akad. Keempat, barang dagangan harus ada di tangan pedagang. Kelima, barang dagangan bisa diestimasi nilainya bisa dari ukurannya, panjangnya, beratnya, dan sifatnya. Keenam, penentuan waktu penyerahan barang. ${ }^{37}$

Selain keenam syarat tersebut, terdapat beberapa syarat lain yang menjadi perdebatan bagi seluruh ulama, namun Abu Hanifah mensyaratkan hal-hal tersebut. Dengan tujuan melindungi pelaku ekonomi dari kerugian akad salam, maka Abu Hanifah mewajibkan syarat-syarat tersebut. ${ }^{38}$

Empat syarat salam yang dianggap perlu oleh Imam Abu Hanifah adalah jangka waktu, wujud barang saat akad, tempat akad, harga empirik. Pertama, Abu Hanifah mewajibkan adanya jangka waktu penyerahan barang kepada pembeli setelah ia membayar kepada penjualnya. Hal ini dimaksudkan untuk meringankan pedagang guna menyiapkan barang dagangannya terlebih dahulu. Kedua, Abu Hanifah mensyaratkan wujud barang saat terjadinya akad. Hal ini berlandasakan pada hadis Ibnu Umar yang mengatakan bahwa Rasulullah SAW bersabda: jangalah melakukan akad salam dalam kurma sebelum ia matang. Abu Hanifah melihat ini sebagai pencegahan dari bai' gharar serta menurutnya jika

${ }^{36}$ Salam adalah akad jual beli di mana pembeli membayar harga di muka, sedangkan barang akan diterima pada saat waktu yang telah disepakat dengan syaratsyarat tertentu. Lihat Wahbah bin Musthafa Al-Zuhaili, Al-fiqhu Al-Islamy wa Adillatubu, jilid 5, (Damaskus: Darul Fikri), h.3603

${ }^{37}$ Sayyid Sabiq, Fiqhu Sunnah, jilid 3, (Mesir: al-Fathu lil I'lami al-'Araby), h.121

${ }^{38}$ Ahmad Maulidizen, Pemikiran dan Kontribusi Tokob Ekonomi Islam Klasik dan Kontemporer, Jurnal Deliberatif Vol 1, No 1, Juni 2017 h.42-62 
wujud barang tidak disyaratkan, maka akad salam akan menjadi mirip dengan bai’ ma lam yukhlaq atau jual beli sesuatu yang belum dibuat. ${ }^{39}$

Ketiga, Ia mensyaratkan adanya tempat terjadinya akad, maka baik muslim atau muslim ilaibi harus datang ke satu tempat untuk melakukan akad. Abu Hanifah mensyaratkan hal ini karena menurutnya tempat penyerahan barang sama pentingnya dengan jangka waktu. ${ }^{40}$ Keempat, harga empirik. Harga emipirik adalah harga barang yang dapat ditentukan berdasarkan berat, panjang, jumlah dan sifat. ${ }^{41}$ Maka, dari hal-hal di atas dapat disimpulkan, bahwa Abu Hanifah sangat amat berhati-hati dalam akad salam yang berbeda dari akad bai' biasa.

\section{Zakat Madu}

Pemikiran ekonomi Imam Abu Hanifah yang akan dibahas selanjutnya adalah zakat madu. Abu Hanifah dan murid-muridnya mengatakan bahwa zakat juga wajib dkeluarkan dari madu, asalkan sarang lebah tidak terletak di lahan kharaj. Sama halnya dengan prinsip mereka yaitu kharaj dan 'ushr tidak boleh bersamaan. Zakat pada madu yang juga diwajibkan bagi madu yang diproduksi di tanah tandus. ${ }^{42}$

Landasan Abu Hanifah mewajibkan zakat madu adalah hadist yang diriwayatkan oleh Ibnu Majjah. Dari Amr bin Syue aib dari bapaknya, dari kakeknya, dari Abdullah bin Amr, dari Nabi SAW bahwasanya ia telah memungut zakat dari madu sebanyak sepersepuluh. ${ }^{43}$

Abu Hanifah memiliki pemikiran bahwa zakat wajib dikeluarkan bagi siapa yang memiliki madu dengan miqdar sama dengan miqdar zakat hasil pertanian, yaitu sepersepuluh. Sedangkan untuk nisab, Abu Hanifah mengatakan bahwa tidak ada nisab bagi zakat madu sebagaimana zakat hasil pertanian. ${ }^{44}$ jadi, sebanyak apapun madu yang dimiliki zakat yang dikeluarkan tetaplah sepersepuluh.

Abu Hanifah merujuk pada hadis rasulullah yang diriwayatkan oleh Ibnu Majah. Dari Abu Sayyarah al-Muta'iy. Ia berkata, "Aku berkata, Wahai

${ }^{39}$ Ibnu Rusyd, Bidayatul Mujtahid wa Nihayatul Muqtashid, jilid 1, (Beirut: Darul Fikri, 2005), h.162-164

${ }^{40} \mathrm{Ibnu}$ Rusyd, Bidayatul Mujtabid wa Nihayatul Muqtashid...

${ }^{41}$ Ibnu Rusyd, Bidayatul Mujtabid wa Nihayatul Muqtashid,... h. 164-165

${ }^{42}$ Yusuf Qardhawi, Fiqhu Zakah, (Beirut: Muassisah Risalah, 1973), h.424

${ }^{43}$ Abi Abdullah Muhammad Ibn Yazid al-Qazwini, Sunan Ibn Majah, vol 1(Beirut: Dar al-Kitab al-Alamiyah), h.584.

${ }^{44}$ Yusuf Qardhawi, Fiqhu Zakah, h.427-429 
Rasulullah, sesunggguhnya aku memiliki lebah (madu)!?.” Rasulullah SAW bersabda, "Keluarkanlah sepersepuluh." Aku berkata, "Wahai Rasulullah, lindungilah ia untukku." Maka beliau pun menjaganya untukku. ${ }^{45}$

Pengeluaran zakat madu disamakan seluruhnya dengan zakat hasil pertanian, baik dari miqdar ataupun waktunya. Adapun miqdar zakat madu adalah sepersepuluh dan dilaksanakan setiap panen bukan tiap tahun. ${ }^{46}$

\section{Akad Hawalah}

Dalam bagian ini akan dibahas mengenai akad hawalah dalam pandangan Imam Abu Hanifah. Hawalah adalah pengalihan hutang daro satu orang ke orang lain. ${ }^{47}$ Contohnya ketika A meminjamkan uang pada $\mathrm{B}$, sedangkan $\mathrm{B}$ memiliki piutang di $\mathrm{C}$, maka B boleh meminta A untuk menagih hutang ke C. Jadi pengalihan hutang terjadi dari tangan B ke tangan C. Dalam fiqh, A disebut dengan muhal, $\mathrm{B}$ disebut dengan muhil dan $\mathrm{C}$ disebut dengan muhal alaih dan akad yang terjadi disebut dengan hawalah.

Asas dari akad ini adalah hadis dan ijma' yang telah disepakati oleh para ulama termasuk Abu Hanifah. Hadis yang diriwayatkan oleh muttafaqun alaih. Dari Abu Hurairah RA berkata: Rasulullah SAW bersabda: menunda pembayarah hutang bagi orang yang kaya adalah suatu kedzaliman, dan jika dialihkan dari kamu kepada orang yang kaya, maka ia harus menerima penyerahan itu. ${ }^{48}$

Rukun hawalah menurut Abu Hanifah adalah ijab dari muhil: "saya mengalihkan hutang kepada fulan". Serta qabul dari muhal dan muhal alaih dengan lafadz: "saya terima, saya ridho atau lain sebagainya. ${ }^{49}$ Sebab Abu Hanifah mewajibkan adanya ridho muhal dan muhal alaih adalah karena hawalah merupakan muamalah dengan muhal alaih dengan mengalihkan kewajiban kepadanya. Hawalah tidak bisa lengkap tanpa adanya ridho dari muhal alaih karena jika ia tidak ridho hawalah tidak akan bisa terjadi. Sedangkan

${ }^{45} \mathrm{Ibnu}$ Majah Abu Abdullah Muhammad bin Yazid al-Qozwiny, Sunan Ibnu Majah, jilid 1, (Mesir: Dar Ihya'i al-Kutub al-'Arabiyyah), h.1824

${ }^{46} \mathrm{Abu}$ Azam Al Hadi, 'Pemikiran Hukum Imam Abu Hanifah Dan Imam AlSyafi'i Tentang Zakat Madu', Al Hikmah, Volume 2, Nomor 1, Maret 2012, h.134

${ }^{47}$ Wahbah bin Mustafa al-Zuhaili, al-Fiqhu al-Islamy Wa Adillatubu, jilid 6, (Damaskus: Darul Fikri), h.4188

${ }^{48}$ Muhammad bin Ismail Abu Abdullah al-Bukhari al-Ja'fi, Sahih Bukhari, jilid 3, (Damaskus: Daar Tauqun Najah, 1422 H), h.94

${ }^{49}$ Abdul Hasib Sanad Athiyah, al-Mu'awadhat al-Maliyah Fi al-Fighi al-Islamy 'Ala Madzhabi al-Imam Abi Hanifah, (Mesir: Fakultas Syari'ah dan Hukum Universitas AlAzhar, 2004), h.166-167 
diwajibkannya ridho muhal karena hutang yang di-hawalah-kan adalah haknya, ia rela dipindahtangankan dari satu orang ke orang lain. ${ }^{50}$

Syarat akad hawalah menurut Abu Hanifah tidak tercantum harus adanya hutang kepada muhal alaih sudah terjadi sebelum akad hawalah. Jadi, menurut Abu Hanifah hutang tesebut tidak harus terjadi sebelum akad hawalah tapi bisa juga terjadi sesudah akad hawalah. ${ }^{51}$ Menurut Abu Hanifah terdapat dua macam, yaitu: mutlaqah dan muqayyadah. Hawalah Muthlaqoh terjadi apabila orang yang berhutang mengalihkan kewajiban membayar hutangnya kepada pihak ketiga padahal pihak ketiga tidak memiliki hutang kepada orang yang memberi hutang. ${ }^{52}$ Sebagai contoh : A berhutang kepada B dan A mengalihkan kewajiban membayar hutang kepada $C$, sementara $C$ tidak punya hutang dan pituang kepada B. ${ }^{53}$

Macam kedua adalah Hawalah Muqayyadah. Yaitu pengalihan piutang dari satu orang ke orang lain dalam bentuk uang bukan dalam bentuk barang. Muhil dalam jenis hawalah ini adalah pemberi utang dan ia mengalihkan haknya kepada pemberi hutang yang lain sedangkan orang yang berhutang tidak berubah atau berganti, yang berganti adalah piutang. ${ }^{54}$

\section{Analisis Pemikiran Imam Abu Hanifah}

Pada bagian ini pemikiran ekonomi Islam Abu Hanifah akan dianalisis dengan pendapat ulama lainnya. Pemikirannya adalah:

Pertama, akad salam. Ia mensyaratkan adanya jangka waktu dalam akad salam, sedangkan Al-Lakhumy dan Imam Malik tidak mewajibkan syarat tersebut, jadi akad salam boleh dilakukan tanpa adanya jangka waktu. Kemudian, Abu Hanifah berpendapat bahwa adanya tempat kejadian merupkan syarat, namun menurut Ibnu Muwaz syarat tersebut tidak diperlukan. ${ }^{55}$ Selain itu, syarat salam menurut Abu Hanifah adalah harga empirik, sedangkan Imam Syafi'i tidak menganggap ini hal yang perlu dijadikan syarat. ${ }^{56}$

Kedua, zakat madu. Abu Hanifah menyatakan bahwa zakat wajib dikeluarkan dari madu sebagaimana zakat hasil pertanian. Namun, Imam Syafi'i

\footnotetext{
${ }^{50}$ Wahbah bin Mustafa al-Zuhaili, al-Fiqhu al-Islamy Wa Adillatubu, jilid 6, h.4189

${ }^{51}$ Abdul Hasib Sanad Athiyah, al-Mu'awadhat al-Maliyah Fi al-Fiqhi al-Islamy 'Ala Madžbabi al-Imam Abi Hanifah, h.169-171

${ }^{52}$ Abdul Hasib Sanad Athiyah..., h.172

53Wahbah bin Mustafa al-Zuhaili, al-Fiqhu al-Islamy Wa Adillatubu, jilid 6, 4194

${ }^{54}$ Wahbah bin Mustafa al-Zuhaili..., h.4195

${ }^{55}$ Ibnu Rusyd, Bidayatul Mujtahid wa Nibayatul Muqtashid, jilid 1, (Beirut: Darul Fikri, 2005), h.162-164

56Ibnu Rusyd..., h.165
} 
kurang setuju dengan pendapat tersebut. Imam Syafi'i tidak mengatakan bahwa madu wajib dizakatkan karena menurutnya madu dari lebah sama halnya sutra dari ulat, maka tidakk wajib mengeluarkan zakat madu. ${ }^{57}$

Ketiga, akad hawalah. Imam Abu Hanifah mensyaratkan ridho muhal dan muhil dalam hawalah, namun yang mewajibkan syarat ini hanyalah Abu Hanifah, tiga imam lainnya (Imam Syafi'i, Imam Malik, dan Imam Hambali) tidak mewajibkan hal ini karena dirasa tidak perlu. Ketidakperluan menurut tiga imam tersebut dikarenakan pastinya ridho muhal dan muhil saat mereka melakukan akad hawalah. ${ }^{58}$ Abu Hanifah tidak mensyaratkan terjadinya hutang sebelum akad hawalah, sedangkan bagi ulama lain hal itu wajib dijadikan syarat. ${ }^{59}$ Kemudian Abu Hanifah juga membolehkan hawalah mutlaqah di mana ketiga imam fiqh tidak memperbolehkannya. ${ }^{60}$

\section{PENUTUP}

Abu Hanifah tidak memiliki gagasan khusus dalam ekonomi, namun Abu Hanifah memiliki banyak pendapat dalam akad-akad muamalat. Beberapa pemikirannya adalah dalam salam, zakat madu dan hawalah. Pemikiran Abu Hanifah dalam akad salam yang berbeda dengan Imam lainnya adalah empat syarat yang diwajibkan oleh Abu Hanifah guna melindungi pelaku ekonomi dari segala macam kerugian. Adapun pemikirannya mengenai zakat madu, ia mewajibkan zakat bagi yang memiliki madu sedangkan imam lainnya tidak mewajibkan hal itu. Dan dalam hawalah Abu Hanifah membolehkan hawalah mutlaqah yang diharamkan oleh imam lainnya. Semua pemikiran Abu Hanifah dilandasi oleh Qur'an, Sunnah, Ijma', Qiyas, Istihsan dan dalil-dalil mukhtalaf lainnya, sehingga terkadang memiliki pemikiran yang berbeda dengan imam lainnya.

Pemikiran-pemikiran Abu Hanifah dalam ekonomi masih bisa digunakan hingga saat ini karena memang ia tidak melandasi pemikirannya atas dasar rasional saja namun juga berdasarkan naqli. Namun alangkah baiknya jika menjauhi ikhtilaf ulama' dengan menjauhi yang diharamkan dan menjalani yang diwajibkan. Maka pada syarat salam dan zakat madu yang diwajibkan oleh Abu Hanifah kepada umat muslim untuk mengikutinya. Namun hawalah mutlaqah

${ }^{57}$ Burhanuddin Abi Hasan Ali bin Abi Bakar, Al Hidayah Syarhu Bidayatil Mujtahid, jilid 2, (Pakistan: Idarah Al-Qur'an Karastani, 1417 H), h.212

${ }^{58}$ Abdul Hasib Sanad Athiyah, al-Mu'awadhat al-Maliyah Fi al-Fiqhi al-Islamy 'Ala Madz̧abi al-Imam Abi Hanifah, h.166-167

${ }^{59}$ Abdul Hasib Sanad Athiyah, al-Mu'awadhat al-Maliyah Fi al-Fighi al-Islamy 'Ala Madzhabi al-Imam Abi Hanifah, h.169-171

${ }^{60}$ Wahbah bin Mustafa al-Zuhaili, al-Fiqhu al-Islamy Wa Adillatubu, jilid 6, h.4194 
baiknya dijauhi karena hal tersebut merupakan hal yang dilarang oleh Imam Syafi'i, Maliki dan Hanbali. Sebagaimana kaidah fiqh al-kburuju min al-kbilafi mustahabbun atau keluar dari masalah khilafiyah itu sunnah.

\section{DAFTAR PUSTAKA}

Abi Bakar, Burhanuddin Abi Hasan Ali bin. Al Hidayah Syarhu Bidayatil Mujtahid, jilid 2. Pakistan: Idarah Al-Qur'an Karastani, 1417 H.

Al Hadi, Abu Azam. "Pemikiran Hukum Imam Abu Hanifah Dan Imam AlSyafi'i Tentang Zakat Madu”. Jurnal Al Hikmah. Volume 2. Nomor 1. Maret (2012).

Al-Dhahabi. Manaqib al-Imam Abu Hanifa wa Sabibaibi. Egypt: Dar al-Kutub al'Arabi.

Al-Ja'fi, Muhammad bin Ismail Abu Abdullah al-Bukhari. Sahih Bukhari. jilid 3. Damaskus: Daar Tauqun Najah, 1422.

Al-Qazwini, Abi Abdullah Muhammad Ibn Yazid. Sunan Ibn Majah. vol 1 Beirut: Dar al-Kitab al-Alamiyah.

Al-Qozwiny, Ibnu Majah Abu Abdullah Muhammad bin Yazid. Sunan Ibnu Majah. jilid 1. Mesir: Dar Ihya'i al-Kutub al-'Arabiyyah.

Al-Zuhaili, Wahbah bin Mustafa. al-Fiqhu al-Islamy Wa Adillatubu. jilid 6. Damaskus: Darul Fikri

Asy-Syahbashi, Ahmad. Al-Aimmah Al-Arba'ah. Mesir: Darul Hilal.

Athiyah, Abdul Hasib Sanad. al-Mu'awadhat al-Maliyah Fi al-Fiqhi al-Islamy 'Ala Madzhabi al-Imam Abi Hanifah. Mesir: Fakultas Syari'ah dan Hukum Universitas Al-Azhar, 2004.

Chamid, Nur. Jejak Langkah Sejarah Pemikiran Ekonomi Islam. Yogyakarta: Pustaka Pelajar, 2010.

Ghawiji, Wahbi Sulaiman. Abu Hanifah Nu'man Imam al-Aimmah al-Fuqaha'. Beirut: Darul Qalam, 1993.

Hind, Ghaus-ul-Waqt Huzoor Mufti-e-Azam. The Importance of Fiqh \& A Brief Introduction to Imam Azam Abu Hanifa. Durban: Imam Mustafa Raza Research Centre, 2014.

Juliansyahzen, M. Iqbal, "Pemikiran Hukum Islam Abu Hanifah: Sebuah Kajian Sosio-Histori Seputar Hukum Keluarga”, Jurnal Al-Madzahib, Volume 3, Nomer 1, Juni (2015). 
Kasdi. Abdurrahman, "Metode Ijtihad Dan Karakteristik Fiqih Abu Hanifah". Jurnal Yudisia, Vol. 5, No. 2, Desember (2014).

Maulidizen, Ahmad. "Pemikiran dan Kontribusi Tokoh Ekonomi Islam Klasik dan Kontemporer". Jurnal Deliberatif Vol 1. No 1. Juni (2017).

Minyak Indonesia Diperkirakan Habis 12 Tahun Lagi: https://ekbis.sindonews.com/read/1225346/34/minyak-indonesiadiperkirakan-habis-12-tahun-lagi-1501398668

Mirakhor, Abbas. 1989. 'Muslim Contribution to Economics. in the book Baqir al-Hasanidan Abbas Mirakhor'. Essays on Iqtisad: The Islamic Approach to Economic Problems. USA: Nur Coorporation

Nadwi, Mohammed Akram. Abu Hanifah: His Life. Legal Method \& Legacy. Leicestershire: Kube Publishing, 2011.

Penduduk Miskin September 2017 Mencapai 10.12 persen: https://www.bps.go.id/pressrelease/2018/01/02/1413/persentasependuduk-miskin-september-2017-mencapai-10-12-persen.html

Qardhawi, Yusuf. Fiqhu Zakah. Beirut: Muassisah Risalah, 1973.

Rusyd, Ibnu. Bidayatul Mujtabid wa Nihayatul Muqtashid. jilid 1. Beirut: Darul Fikri, 2005.

Sabiq, Sayyid. Fiqhu Sunnah. jilid 3. Mesir: al-Fathu lil I'lami al-'Araby.

Sugiono. Metode Penelitian Kuantitatif. Kualitatif Dan R \& D. Bandung: Alfabeta, 2014.

Zahra, Muhammad Abu. Imam Abu Hanifa. His Life. Opinions and Fiqh. Makkah: Maktabah Publication, 1945.

Zida, Abdul Karim. Al-Wajir fi Usul Fiqh. Giza: Muassasah Cordova, 1976 
44 |Al-Falah: Journal of Islamic Economics, Vol.3, No.1, 2018 